\title{
Mycobacterium Tuberculosis Infection Following Kidney Transplantation
}

\author{
Karima Boubaker*, Ezzedine Abderrahim, Taieb Ben Abdallah, Adel Kheder \\ Research Laboratory of Immunology, Internal Medecine Department, Charles Nicole Hospital, Tunis \\ *Corresponding author: ranou04@yahoo.fr
}

Received June 05, 2013; Revised August 16, 2013; Accepted August 19, 2013

\begin{abstract}
Fertility is considerably affected in chronic renal insufficiency and periodic hemodialysis and is improved by renal transplantation. Transplanted patients recover from their renal failure state and, pregnancy occurred in $2 \%$ in renal graft recipients in age to procreate. The aim of our study is to bring back the cases of pregnancies carried out in our renal patients transplanted and to specify the possible complications of the foetus and the mother schools to the course or after the childbirth. It is a retrospective study over one 20 years period of 1986 to 2006 of 10 pregnancies occurred in 7 renal transplant recipients followed in our Charles Nicole hospital department. Mean patient age was 33,8 years (29- 43 years). Mean time between transplantation and the onset of pregnancy was 6.5 years (1-18 years). Before pregnancy, hypertension was observed in 1 case and proteinuria in other case. All our patients had creatininemia $<1,50 \mathrm{mg} / \mathrm{dl}$. Immunosuppressive treatment associated steroids and azathioprin in 3 cases, steroids and ciclosporin A in 2 cases and steroids, ciclosporin A and azathioprin in 2 cases. One patient developed diabetes. Maternal complications were rare, essentially hypertension in 2 cases, proteinuria in 1 case, ascension of creatininemia in 2 cases and hepatic cholestase in 2 cases. Deliverance was at time in 8 cases. Prematurity was observed in 2 cases; it was related to premature rupture of membranous in 1 case and uterine contractions in cesarean patient in other case. The mean neonatal weight was $2950 \mathrm{~g}$ (2100- $3500 \mathrm{~g}$ ) with 4 small for gestational age $(<2800 \mathrm{~g})$. It was noted 1 case of newborn down's syndrome in a pregnant women aged of 37 years. After a mean follow up of 7,4 years follow-up, mean cretininemia was $1,80 \mathrm{mg} / \mathrm{dl}(0,74-5,53 \mathrm{mg} / \mathrm{dl})$. One patient showed chronic rejection. Immunosuppressive treatment seemed without adverse effects on fetus. The only case of chromosome abnormality was appeared in a pregnant women aged more than 35 years. The course of pregnancy after renal transplantation is generally uncomplicated without increased risk of graft loses. However, a normal arterial pressure, a stable renal function and absence of proteinuria are requested before allowing a pregnancy.
\end{abstract}

Keywords: renal transplantation-pregnancy

Cite This Article: Karima Boubaker, Ezzedine Abderrahim, Taieb Ben Abdallah, and Adel Kheder, "Mycobacterium Tuberculosis Infection Following Kidney Transplantation." American Journal of Infectious Diseases and Microbiology 1, no. 4 (2013): 79-83. doi: 10.12691/ajidm-1-4-5.

\section{Introduction}

Women with end-stage chronic renal failure have low fertility and high-risk pregnancies [1]. Kidney transplantation in most cases restores fertility for these women [2,3]. 14000 births in the whole world were reported in organ transplant recipients [4]. The first pregnancy after organ transplantation was described in 1963 in a woman who had received a kidney allograft [2] and since successful pregnancies were reported in $2 \%$ of kidney transplant recipients of childbearing age $[5,6]$. However, pregnancy in kidney transplant recipients is not without risks $[1,7]$. The course of the pregnancy is favorable by respecting the recommendations such as the European recommendations of good practices IV $[1,8]$. The objective of our study was to study the course of pregnancy after kidney transplantation and to assess the impact of the pregnancy on the on the fetus and on the kidney graft.

\section{Patients and Methods}

\subsection{Patients}

This is the retrospective study of the medical histories of 312 kidney transplant recipients whose operations were performed between 1986 and 2006 in our hospital.

Kidney transplant recipients received likely a living related graft in 241 cases, a non related graft in 17 cases and a cadaveric graft in 54 cases.

Among the 107 kidney transplantation in females, 10 spontaneous pregnancies occurred in 7 kidney transplant recipients.

We had contra-indicated pregnancy during the first 2 years after kidney transplantation.

\subsection{Methods}

Patients were reviewed in terms of reason for kidney failure, type of dialysis (hemodialysis or peritoneal 
dialysis), length of pretransplant dialysis and age at kidney transplantation. For donors, these demographics included age, sex, blood group, type of donor (deceased or living), and relationship to the recipient.

For each patient, transplantation-pregnancy interval, age at diagnosis of pregnancy, immunosuppressive regimen, function of the kidney at the time of diagnosis of pregnancy circumstances of discovery of the pregnancy and its complications were reviewed. Arterial pressure and labour values were all evaluated.

Graft function and mortality rate were also reviewed.

The infants' general health and follow-up were examined closely. The mode of delivery (natural childbirth or Cesarean section), the baby's weight, length, head circumference, Apgar score and labor values were all evaluated.

Low-birth-weight is defined by weight between 1500 and $2500 \mathrm{~g}$ and very low-birth-weight by weight between 1000-1500 g at birth. Premature babies are delivered between gestational weeks 29 and 37 .

We also inquired about growth, laboratory tests, and the last measured height and weight.

\section{Results}

The mean age at kidney transplantation was 28,5 years (25-35 years). Causes of the end stage renal stage were interstitial in 3 cases (nephronophtis in 1 case), glomerular in 2 cases (IgA nephropathy in 1 case and membranous nephropathy in 1 case) and unknown in 2 cases.

Kidney transplant recipients received a living related graft in 5 cases and a cadaveric graft in 2 cases. Immunososuppressive regimen associated steroids and azathioprine with or without ciclosporine. A patient presented a microscopic hematuria and a graft dysfunction explained by the recurrence of Ig A nephropathy on the kidney graft. A hypertension was observed in 2 cases, a proteinuria in 2 cases under than $1 \mathrm{~g} / 24$ hours, anemia in 1 case and post transplantation diabetes in 1 case. The mean serum creatininemia before pregnancy was at $1,03 \mathrm{mg} / \mathrm{dl}$ (0,81- 1,47 mg /dl).

No case of acute rejection of the graft was observed before diagnosis of pregnancy. Patients had regular menstrual cycles and were not under contraception (Table 1).

Table 1. Clinical exam and biology before pregnancy

\begin{tabular}{|c|c|c|c|c|c|c|c|c|c|c|c|c|}
\hline No & NI & $\begin{array}{c}\text { Age at } \\
\text { KT } \\
\text { (year) }\end{array}$ & $\begin{array}{c}\begin{array}{c}\text { Donor age } \\
\text { years) }\end{array} \\
\end{array}$ & Ttt IS & $\begin{array}{l}\mathrm{BP} \\
\mathrm{cmHg}\end{array}$ & Treatment & $\begin{array}{c}\text { Creat } \\
\mathrm{mg} \\
/ \mathrm{dl} \\
\end{array}$ & $\begin{array}{c}\text { Gly } \\
\mathrm{mmol} / \mathrm{l}\end{array}$ & $\begin{array}{c}\text { Uric } \\
\text { acid } \\
\mu \mathrm{mol} / \mathrm{l} \\
\end{array}$ & $\begin{array}{l}\mathrm{Hb} \\
\mathrm{g} / \mathrm{dl}\end{array}$ & $\begin{array}{l}\text { Hepatic } \\
\text { biology }\end{array}$ & $\begin{array}{c}\text { 24h- } \\
\text { Proteinuria } \\
\text { (g) }\end{array}$ \\
\hline 1 & \multirow{2}{*}{$\begin{array}{c}\text { NIC/PBR: } \\
\text { nephronophthisis }\end{array}$} & \multirow{2}{*}{28} & \multirow{2}{*}{$\begin{array}{l}\text { Mother } \\
\text { (47) }\end{array}$} & \multirow{2}{*}{$\begin{array}{l}\text { CS- } \\
\text { AZT }\end{array}$} & $11 / 7$ & 0 & 0,98 & 5,8 & 264 & 13,2 & $\mathrm{Nl}$ & 0 \\
\hline 2 & & & & & $12 / 8$ & 0 & 0,94 & 5 & 317 & 12,6 & $\mathrm{Nl}$ & 0 \\
\hline 3 & NIC/RVU & 28 & $\begin{array}{l}\text { Mother } \\
\text { (57) }\end{array}$ & $\begin{array}{c}\text { CS- } \\
\text { AZT- } \\
\text { CicloA } \\
\end{array}$ & $12 / 8$ & 0 & 1,36 & 4,8 & 435 & 9,5 & $\mathrm{Nl}$ & 0 \\
\hline 4 & \multirow{2}{*}{$\begin{array}{c}\text { NGC/PBR : IgA } \\
\text { nephropathy }\end{array}$} & \multirow{2}{*}{25} & \multirow{2}{*}{ deceased } & \multirow{2}{*}{$\begin{array}{l}\text { CS- } \\
\text { AZT }\end{array}$} & $11 / 6$ & 0 & 1,47 & 5,7 & 393 & 12,2 & $\mathrm{Nl}$ & 0,5 \\
\hline 5 & & & & & $12 / 8$ & metoprolol & 1,39 & 5 & 378 & 12,2 & $\mathrm{Nl}$ & 0,8 \\
\hline 6 & \multirow{2}{*}{ NIC } & \multirow{2}{*}{23} & \multirow{2}{*}{$\begin{array}{c}\text { Mother } \\
(44)\end{array}$} & \multirow{2}{*}{$\begin{array}{c}\text { CS- } \\
\text { CicloA }\end{array}$} & $11,5 / 7$ & 0 & 0,91 & 5,2 & 309 & 14,2 & $\mathrm{Nl}$ & 0 \\
\hline 7 & & & & & $9 / 6$ & 0 & 0,81 & 5 & 300 & 13,5 & cytolysis & 0 \\
\hline 8 & $\begin{array}{c}\text { NC/PBR } \\
\text { inconclusive }\end{array}$ & 31 & deceased & $\begin{array}{c}\text { CS- } \\
\text { CicloA } \\
\end{array}$ & $13 / 9$ & metoprolol & 0,84 & 4,4 & 205 & 13,5 & $\mathrm{Nl}$ & 0 \\
\hline 9 & NGC/PBR: GEM & 35 & $\begin{array}{l}\text { Brother } \\
\text { (30) }\end{array}$ & $\begin{array}{c}\text { CS- } \\
\text { AZT- } \\
\text { CicloA } \\
\end{array}$ & $11 / 6$ & 0 & 0,81 & $\begin{array}{c}5,8 \\
\text { (diabetes) }\end{array}$ & 334 & 12,6 & $\mathrm{Nl}$ & 0 \\
\hline 10 & NC & 30 & $\begin{array}{l}\text { Brother } \\
(30)\end{array}$ & $\begin{array}{l}\text { CS- } \\
\text { AZT }\end{array}$ & $12 / 8$ & 0 & 0,80 & 5 & 300 & 12 & $\mathrm{Nl}$ & 0 \\
\hline
\end{tabular}

AZT: azathioprin, BP: blood pressure, Cs : steroids, CicloA: ciclosporine, Creat: creatininemia, Gly: glycemia, Hb: haemoglobin, K T : kidney transplantation, Nl: normal, Prot/24h: 24-hours proteinuria.

Circumstances of discovery of the pregnancy were delay of the menstruations in all the cases. The mean interval from transplantation to pregnancy was 6,5 years (1-18 years) and it was higher than 2 years in $70 \%$ of the cases. The mean age at diagnosis of pregnancy was 33,8 years (29-43 years).

No modification of immunosuppressive regimen was noted during pregnancy.

The mean creatininemia during pregnancy was constant at $1,04 \mathrm{mg} / \mathrm{dl}(0,77-1,88 \mathrm{mg} / \mathrm{dl})$ with the creatininemia higher than $1,5 \mathrm{mg} / \mathrm{dl}$ in 2 cases.

\begin{tabular}{|c|c|c|c|c|c|c|c|c|c|}
\hline $\mathrm{N}^{\circ} \mathrm{G}$ & Interval KT/P (years) & BP cmHg & Treatment & $\begin{array}{c}\text { Creat } \\
\mathrm{mg} / \mathrm{dl}\end{array}$ & $\begin{array}{c}\text { Gly } \\
\mathrm{mmol} / \mathrm{l}\end{array}$ & $\begin{array}{c}\text { Uric acid } \\
\mu \mathrm{mol} / \mathrm{l}\end{array}$ & $\begin{array}{l}\mathrm{Hb} \\
\mathrm{g} / \mathrm{dl}\end{array}$ & Hepatic biology & $\begin{array}{l}\text { 24h- Proteinuria } \\
\text { (g) }\end{array}$ \\
\hline 1 & 1 & $10,5 / 8$ & 0 & 0,83 & 5,5 & 273 & 9,8 & $\mathrm{Nl}$ & 0 \\
\hline 2 & 3 & $11,5 / 7$ & 0 & 0,77 & 5 & 274 & 10 & $\mathrm{Nl}$ & 0 \\
\hline 3 & 2 & $12 / 8$ & Acebutolol & 1,60 & 5 & 532 & 7,5 & $\mathrm{Nl}$ & 0 \\
\hline 4 & 12 & $11 / 6$ & 0 & 1,88 & 5,5 & 525 & 12 & $\mathrm{Nl}$ & 1,5 \\
\hline 5 & 18 & $13 / 9$ & metoprolol & 1,40 & 5 & 458 & 12,2 & $\mathrm{Nl}$ & 0,9 \\
\hline 6 & 7 & $12 / 8$ & 0 & 0,75 & 5 & 291 & 10,8 & cholestasis & 0 \\
\hline 7 & 10 & $12 / 8$ & 0 & 0,75 & 5 & 300 & 10,4 & cholestasis & \\
\hline 8 & 4 & $11 / 8$ & Acébutolol & 0,94 & 5 (diabetes) & 300 & 8,7 & $\mathrm{Nl}$ & 0,8 \\
\hline 9 & 2 & $12 / 8$ & 0 & 0,76 & 5,5 & 501 & 12 & cholestasis & 0 \\
\hline 10 & 6 & $12 / 8$ & 0 & 0,80 & 5 & 300 & 11 & $\mathrm{Nl}$ & 0 \\
\hline
\end{tabular}

BP: blood pressure, Creat: creatininemia, Gly: glycemia, Hb: haemoglobin, K T : kidney transplantation, Nl: normal, P:pregnancy, Prot/24h: 24-hours proteinuria.

Pregnancy complications included new-onset proteinuria in 1 cases in the third trimester and the onset of hypertension without proteinuria in 1 case. The hypertension was associated with proteinuria in 3 cases. Graft dysfunction during pregnancy was observed in 2 cases, hepatic cholestasis in 2 cases and hyperuricemia in 
4 cases. No peripartum maternal deaths were reported (Table 2).

Fetal complications were premature in 3 cases caused by a premature rupture of the membranes in 1 case, uterine contractions on cicatricial uterus in 1 case and preeclampsia in the third case. Mean weight at the birth was 2950 g (2100 - 3500 g) with 4 cases of low-birthweight. A patient presented an allograft dysfunction caused by an infection of the amniotic liquid. Postpartum was without complications in all the cases. Only one patient was lost to follow-up after the childbirth. Six patients were followed.

After a mean follow-up of 7,4 years (2-14 years) after childbirth, blood pressure was normal in 3 patients and hypertension was observed in 3 patients. No acute rejection was noted. Renal function remained stable in 9 cases. A puncture biopsy of the graft practised in the patient having creatininemia at $5,53 \mathrm{mg} / \mathrm{dl}$ showed chronic allograft dysfunction and chronic ciclosporine toxicity with tubulointerstitial and vascular lesions.

Concerning the 3 patients who had 2 pregnancies, after a follow-up respectively of 4, 6 and 14 years, hypertension was noted in 2 cases, creatininemia was respectively at 1,12; 1,40 and 1,06 $\mathrm{mg} / \mathrm{dl}$ and proteinuria was observed in 1 case.

One death was observed 8 years after the childbirth secondary to colic cancer.

Growth was normal for 9 children. Only one baby had a down's syndrome whose mother was 36 years old (Table $3)$.

Table 3. Complications in Fetuses or Neonates and kidney recipients mothers

\begin{tabular}{|c|c|c|c|}
\hline No & Follow-up (years) & Fœtus & Mothers \\
\hline 1 & 14 & - & HBP \\
\hline 2 & 12 & - & cesarean section \\
\hline 3 & 4 & Preterm delivery- & cesarean section -HBP-prot =0,5g/24h \\
\hline 4 & 11 & - & RAS \\
\hline 5 & 5 & - & ARF (amniotic infection) - cesarean section HBP-CGD-prot =0,6g/24h death \\
\hline 7 & 7 & - & cesarean section \\
\hline 8 & 4 & Preterm delivery & - \\
\hline 9 & 2 & - & \\
\hline 10 & Lost to follow-up & Down's syndrome & \\
\hline
\end{tabular}

ARF: acute renal failure, CGD: chronic graft dysfunction, HBP: High blood pressure.

\section{Discussion}

In this study, $6,5 \%$ of childbearing age women experienced pregnancy, an incidence that was lower than that recently reported. Since successful pregnancies were reported in $2 \%$ of kidney transplant recipients [5,6].

All pregnancies occurred after 1 year post transplantation; creatininemia was lower than $150 \mu \mathrm{mol} / \mathrm{l}$ in all cases, normal blood pressure under treatment in 2 cases and a proteinuria under than $1 \mathrm{~g} / 24$ hours in 2 cases.

The maternal complications during the pregnancy were gravidic arterial hypertension in 3 cases, proteinuria in 3 cases, hepatic cholestasis in 2 cases hyperuricemia in 4 cases. A patient presented an acute renal failure due to amniotic liquid infection. The foetal complications were prematurity in 3 cases and a fetal hypotrophy in 4 cases. One case of Down's syndrome whose mother was 36 years old is noted.

Kidney transplantation improved the fertility in chronic failure patients [1]. Several registers studied the course of these pregnancies $[9,10]$.

These pregnancies were rare, occurring in $97 \%$ of cases after the first year of kidney transplantation [11]. All our patients carried out a pregnancy after the first year of renal transplantation. The mean age at the time of these patients was $29 \pm 5$ years comparable with that of our patients [11].

Multiple pregnancies are rarer [12].

Pregnancy must be planned since risk factors increase of $75 \%$ the maternal and/or fetal complications $[6,13,14,15]$.

The risk factors are a short interval between kidney transplantation and pregnancy lower than 2 years, a pre conceptionnel controlled hypertension, a creatininemia $>1,50$ $\mathrm{mg} / \mathrm{dl}$ and a proteinuria. Immunosuppressive treatment must be adapted [16,17,18,19].
Prematurity in these patients is more frequent in our study and in literature than in general population (30\% to $92 \%$ versus $12,5 \%$ ) [19-24]. Prenatal steroid therapy is indicated in some cases to reach fetal pulmonary maturation [25]. In our series, a prematurity was observed in 2 cases.

The fetal hypertrophy is more frequent than in the general population (8 to $45 \%$ versus $5 \%$ ) particularly when creatininemia $>1,50 \mathrm{mg} / \mathrm{dl}$, there is an hypertension [23,26,27] and during a treatment by ciclosporine compared to the azathioprine $[28,29,30]$. In our series, the fetal hypertrophy was observed in 4 cases in spite of a creatininemia lower than $1,50 \mathrm{mg} / \mathrm{dl}$ in our patients.

Opportunist infections are life threating of the fetus [25].

The teratogenicity risk of the immunosuppressive drugs is possible with important doses except mycophenolate mofetil taken during the pre-conceptional period responsible for cranio-facial and cardiovascular malformations [28,29,30,31,32].

It is then recommended to plan a pregnancy if doses of corticoids are lower than $15 \mathrm{mg} / \mathrm{j}$, of ciclosporine lower than $15 \mathrm{mg} / \mathrm{j}$ and azathioprine lower than $2 \mathrm{mg} / \mathrm{kg} / \mathrm{j}$ [3]. It is also recommended to stop the mycophenolate mofetil and to replace it by the azathioprine 2 months before conception. In our series, the only case of chromosomal aberration appeared with the waning of a late pregnancy.

We have not noted any case of neonatal mortality which is more important in literature than that in general population (1 to $39 \%$ versus $0,68 \%$ ) [23]. After the birth, the psychomotor development of the children is normal [12].

The maternal complications are mainly hypertension in 38 to $56 \%$ aggravated by steroids and ciclosporine $[20,28,29,30,33]$. These patients can be treated by beta blocker, alpha-methyl dopamine, hydralazine or calcium blocker [34]. Hypertension is responsible for pre eclampsia in 20 to $30 \%$ of cases in these patients 
[11,13,16,20,25]. In our study, a gravidic hypertension was observed in 3 cases, accompanied by a rise of the creatininemia in 1 case, a proteinuria in 2 cases and a hyperuricemia in 2 cases. Disturbances of the hepatic enzymes during pregnancy are frequent and due to multiple causes [12,35,36].

Infections particularly urinary tract infections are frequent in these patients [37,38,39,40].

Gestational diabetes occurs in 1 to $11 \%$ of cases in these patients [11,41].

Vaginal is proposed in 1st intention in these patients [42].

Acute rejection is similar or even lower than in general population $[19,13,26,43,44]$, in the absence of risk factors, which can explained anti-HLA antibodies made during and after the pregnancy [45]. We did not observe any case of acute rejection in our study.

The incidence of the chronic graft dysfunction of the graft is also similar to the general population of the renal persons receiving a transplant when the creatininemia is lower than $150 \mu \mathrm{mol} / \mathrm{l}[5,16,27,46]$. In our study, observed only one case of chronic graft dysfunction explained by ciclosporine toxicity.

\section{Conclusion}

Pregnancy in kidney recipient's patients is at high risk of fetal complications. It is reasonable to wait at least a period of 1 year after kidney transplantation to program a pregnancy, to have a normal blood pressure, a stable renal function (creatininemia $<1,50 \mathrm{mg} / \mathrm{dl}$ ), absence of proteinuria and adapted immunosuppressive treatment. A multidisciplinary collaboration between nephrologist's transplants, gynecologists and podiatrists is mandatory.

\section{References}

[1] Fuchs KM, Wa D, Ebcioglu Z. Pregnancy in renal transplant recipients. Semin Perinatol 2007;31:339.

[2] Audra P et Laville M. Grossesse après greffe de rein. Encycl Med Chir, (Elsevier, Paris), Gynécologie/Obstétrique, 5-016-B-22, 1996, 4p.

[3] Ville Y, Fernandez H, Edouard D, Frydman R. La grossesse après transplantation rénale. À propos de 27 patientes et revue de la littérature. J Gynecol Obstet Biol Reprod, 1992 ; 21 : 683-9.

[4] Mc Kay DB, Josephson MA. Pregnancy in recipients of solid organs-effects on mother and child. N Eng J Med; 2006;354: 1281.

[5] First MR, Combs CA, Weiskittel P, Miodovnik M. Lack of effect of pregnancy on renal allograft survival or function. Transplantation, 1995; 59: 472-6.

[6] Davison JM. Dialysis, transplantation, and pregnancy. Am J Kidney Dis, 1991; 17: 127-32.

[7] Ben Youssef R, Iwaki Y, Baron P et al. Successful living related kidney transplantation across an anti-donor HLA antibody. Transplant Proc 2006;38-1280.

[8] O” Bas aran, Emirog R, Scc S et al. Pregnancy and renal transplantation. Transplant Proc $2004 ; 36$ :122.

[9] Coscia LA, Constantinesca S, Moritz MJ et al. Report from the National Transplantation Pregnancy registry (NTPR) : outcomes of pregnancy after transplantation. National Transplantation Pregnancy Registry. Clin Transpl 2007;29,Review.

[10] Sibanda N, Briggs JD, Davison JM et al. Outcomes of pregnancy after renal transplantation : a case report of UK Transplant Pregnancy Registry. Hypertens Pregnancy 2004;23:136.

[11] Levidiotis V, Chang S, McDonald S. Pregnancy and maternal outcomes among kidney transplant recipients. J Am Soc Nephrol.2009;20:2433-40.

[12] Nicovani V et al. Successful multiple pregnancy (triplets) in a kidney transplant recipient: a case report. Transplant Proc 2009;41:2688-90.
[13] Davison JM. Towards long-term graft survival in renal transplantation: pregnancy. Nephrol Dial Transplant, 1995; 10 (suppl 1): 85-9.

[14] Fitoussi A, Lefebvre G, Frantz P, Luciani J, Camus M, Clough K, et al. Analyse de 10 cas de grossesse après transplantation rénale. J Gynecol Obstet Biol Reprod, 1990 ; 19 : 69-76.

[15] Ross FL. Ethical considerations related to pregnancy in transplant recipients. N Eng J Med 2006;354:1313.

[16] Rizzoni G, Ehrich JHH, Broyer M, Brunner FP, Brynger H, Fassbinder W, et al. Successful pregnancies in women on renal replacement therapy: report from the EDTA registry. Nephrol Dial Transplant, 1992; 7: 279-87.

[17] Armenti VT, Ahlswede KM, Ahlswede BA, Cater JR, Jarrell BE, Mortiz MJ, et al. Variables affecting birthweight and graft survival in 197 pregnancies in cyclosporine-treated female kidney transplant recipients. Transplantation, 1995; 59: 476-9.

[18] Armenti VT, Constantinescu S, Moritz MJ, Davison JM. Transplantation Reviews 2008;22:223-40.

[19] Framarino dei Malatesta M, Rossi M, Rocca B et al. Fertility following solid organ transplantation. Transplan Proc 2007;39:2001-4.

[20] Armenti VT, Ahlswede KM, Ahlswede BA, Cater JR, Moritz MJ, Burke JF. National transplantation pregnancy registry: analysis of outcome/risks of 394 pregnancies in kidney transplant recipients. Transplant Proceedings, 1994; 26: 2535.

[21] Muirhead N, Sabharwal AR, Rieder MJ, Lazarovits AI, Hollomby DJ. The outcome of pregnancy following renal transplantation. The experience of a single center. Transplantation, 1992; 54: 42932.

[22] Davison JM, Lind T, Uldall P. Planned pregnancy in a renal transplant recipient. Br J Obstet Gynaecol, 1976; 83: 518-27.

[23] Blowey DL, Warady BA. Outcome of infants born to women with chronic kidney disease. Adv Chronic Kidney Dis 2007;144:199205.

[24] Rudolph J, Schweizer R, Bartus S. Pregnancy in renal transplant patients. Transplantation, 1979; 27: 26-9.

[25] Hibbard JU. Obstetric considerations in the management of pregnancy in kidney transplant recipients. Adv Chronic Kidney Dis. 2007;14:168-77.

[26] Framarino di Malatétaita ML, Poli L, Pierucci F, Paolucci A, Pretagostini R, Di Nicuolo A, et al. Pregnancy and kidney transplantation: clinical problems and experience. Transplant Proceedings, 1993; 25: 2188-9.

[27] Nojima M, Ihara H, Ichikawa Y, Fujimoto N, Fukunishi T, Arima $\mathrm{M}$, et al. Influence of pregnancy on graft function after renal transplantation. Transplant Proc, 1996; 28: 1582-5.

[28] Haugen G, Fauchald P, Sodal G, Leivétaitad T, Moe N. Pregnancy outcome in renal allograft recipients in Norway. The importance of immunosuppressive drug regimen and health status before pregnancy. Acta Obstet Gynecol Scand, 1994; 73: 541-6.

[29] Pickrell MD, Sawers R, Michael J. Pregnancy after renal transplantation: severe intrauterine growth retardation during treatment with cyclosporin A. Br Med J, 1988; 296: 825.

[30] Williams P, Brons I, Evans D, Robinson R, Calne R. Pregnancy after renal transplantation. Br Med J, 1988; 296: 1400.

[31] Anderka MT, Lin AE, Abuelo DN, Mitchell AA, Rasmussen SA. Reviewing the evidence for mycophenolate mofetil as a new teratogen: case report and review of the literature. Am J Med Genet A. 2009;149:1241-8.

[32] Dei Malatétaita MF, Rocca B, Gentile T, Hadjistilianou T, Borri M, de Francesco S, Pisani F, Famulari A. A case of coloboma in a newborn to a woman taking mycophenolate mofetil in pregnancy after kidney transplantation.Transplant Proc. 2009;41:1407-9.

[33] Bererhi L, Bedrossian J, Metivier F, Duboust A, Fornairon S, Marrast AC, et al. Pregnancy in kidney transplantation: past and present experience. Transplant Proc, 1997; 29: 2478.

[34] Carosella ED. HLA-G: from feto-maternal tolerance to organ grafting Bull Mem Acad R Med Belg. 2009;164(3-4):87-99; discussion 99-101.

[35] Rahman TM, Wendon J. Severe hepatic dysfunction in pregnancy. QJ Med 2002;95:343-57.

[36] Pereira SP, O’Donohue J, Wendon J, William R. Maternal and perinatal outcome in severe pregnancy - related liver disease. Hepatology 1997;26:1258-62.

[37] Bouattar T, Hakim H, Rhou H, Benamar L, Bayahia R, Ouzeddoun N. Pregnancy in renal transplant recipients. Transplant Proc 2009;41:1586-8. 
[38] Caplan RM, Dosetor JB, Maughan GB. Pregnancy following cadaver kidney homotransplantations. Am J Obstet Gynecol 1970;106:644.

[39] Chaouat G, Szekeres -Bartho J, Menu E and al. Immunologie de la relation materno-foetale. Med Sci $1989: 20-26$

[40] Hamid AH. Pregnancy in renal transplant recipients : a review. Obstet Gynecol Suurv 1986; 41: 264-71.

[41] Gutiarrez MJ et al. Renal allograft function and cardiovascular risk in recipients of kidney transplantation after successful pregnancy.Transplant Proc 2009;41:2399-402.

[42] Penn I, Makowski EL, Harris P. Parenthood following renal and hepatic transplantation. Transplantation, 1980; 30: 397-400.
[43] Tanabe K, Kobayashi C, Takahashi K, Sonda K, Kawai T, Fuchinove $\mathrm{S}$, et al. Long term renal function after pregnancy in renal transplant recipients. Transplant Proc, 1997; 29: 1567-8.

[44] Moritz MJ. Pregnancy outcomes in female renal transplant recipients. NDT 2002;24:55

[45] Cornella C, Riboni F, Pratico L et al. Pregn,ancy and renal transplantation : A case report of the risk of antibody induction against partner antigens. Transpl Proc 2009;41:3964-6.

[46] Thompson BC, Kingdon EJ, Tuck SM et al. Pregnancy in renal transplant recipients: the Royal Free Hospital experience. QMJ 2003;96:837. 